\title{
Max Charlesworth's Sophia: The First Half-Century and the Next
}

\author{
Jay L. Garfield
}

Published online: 20 December 2012

(C) Springer Science+Business Media Dordrecht 2012

When Professor Max Charlesworth, OAM ${ }^{1}$, founded Sophia in 1962 in Melbourne as a journal of philosophical theology, he certainly knew that he was cutting against the grain in Anglophone philosophy in one sense: he was advocating the explicit integration of philosophical and religious concerns and a dialogue between philosophy and religious studies. In doing so, he challenged the self-conception of the discipline of philosophy, a self-conception that has changed but little over the past half century. Philosophy saw and sees itself as constructed, since the Galileo affair, against religion. Religion is represented as its irrational opponent, philosophy as the voice of reason uncontaminated by revelation, spiritual practice or ritual.

Now Charlesworth knew that that self-conception was built on a self-deception. For Anglophone philosophy was conceived in a religious tradition - albeit leavened by the critical tradition of the philosopher and his teacher. Thus, despite the resolute denial of this fact by many of its practitioners, philosophy derives much of its problematic and many of its analytical tools and intuitions from that tradition. How, for instance, can we discuss the freedom of the will outside of a tradition that invented the 'will' as a solution to a particular problem in theodicy - that of the responsibility of an Abrahamic deity for the Fall of Adam in the garden of Eden? How can we take seriously an ethics that presupposes freedom and a transcendental command outside of a tradition involving a transcendental deity who is the arbiter of good and evil? And why posit or worry about a permanent self if we aren't worried about damnation or salvation?

\footnotetext{
${ }^{1}$ Medal of Order of Australia

J. L. Garfield $(\bowtie)$

Smith College, Northampton, MA, USA

e-mail: jgarfiel@smith.edu

J. L. Garfield

Melbourne University, Melbourne, Australia

J. L. Garfield

University of Tibetan Tibetan Studies, Sarnath, India
} 
In defining Sophia as he did, Charlesworth challenged Western philosophy to take its heritage seriously and to face its theological grounding honestly in dialogue with those who understand that ground. That he succeeded in bringing so many philosophers, theologians and scholars of religion to the discussion Sophia enabled is testimony to his philosophical vision and to the willingness of some in these disciplines to put the false sense of boundaries behind them. It is also testimony to the excellent team Charlesworth put together and his fine stewardship of Sophia.

But the decision to bring Philosophy and Religious Studies together as partners in Sophia was radical in another way, perhaps not in the forefront of the consciousness of the editors at its founding, but certainly distinctive of Sophia as it has evolved. For Anglophone western philosophy defined itself self-deceptively not only in contrast to religion, but also in contrast to Asia, Africa and the world's indigenous peoples. To practice philosophy was - and still often is - not only to disavow the roots of one's practice within the tradition one acknowledges as one's own, but also to disavow any interest in the texts, insights or arguments of anyone writing outside of Europe. Philosophy, as it was then conceived in the Euro-American-Australasian world, and as it is still often conceived, is Western philosophy.

Given that the majority of the world's philosophical speculation and writing is nonEuropean, and given that the ground most often given for ignoring non-Western philosophy is the uniquely rational and non-religious character of Western philosophy as opposed to the irrational and religious character of non-Western philosophy, this willingness to renounce interest in so many traditions without bothering to inquire into their contents is ironic, even laughable. It presupposes a kind of direct mystical insight by Europeans into texts they have never read justifying never reading them. And so, with the exception of Philosophy East and West and specialty journals in Asian philosophy that arose much later, professional philosophers in the European, American and Australasian orbits were content to remain hermetically sealed in rational retreat from the rest of the world. Considering Descartes' arguments for the existence of God philosophically, they had no time for the obviously religious discussions of the relation of perception to inference by Dharmakīti, Kumārila or Gañgeśa.

Western religious studies and theology were different, though. With one eye on doctrinal studies and another on the social science and anthropology of religious practice, these disciplines self-consciously sought cultural difference, engaged in comparison and finally in dialogue. They were committed to philology, but also to doctrinal understanding. And so non-Western philosophy came to the West not principally through professional philosophy but through philology, theology and religious studies.

This, of course, was a mixed blessing. On the one hand, we have theologians, philologists and scholars of religion to thank for careful translation, transmission and research into these philosophical traditions and to awakening Western philosophy from its dogmatic and somewhat mystical slumber. On the other hand, this mode of transmission added to the stigma of religion attached to non-Western philosophy in the Western philosophical academy, accounting for the fact, for instance, that attention to Indian epistemology or logic is far greater at meetings of the American Academy of Religion than at the American Philosophical Association and that the Australasian Association for Buddhist Studies is the preferred venue in Australia for Buddhist philosophy, not the Australasian Association of Philosophy. 
All of this brings me back to the real genius of Max Charlesworth's decision to define and to lead Sophia as he did. By joining the cosmopolitan disciplines of religious studies and theology to the doctrinally analytic discipline of philosophy in a single periodical forum, he guaranteed non-Western philosophy a place in the philosophical discourse of the West, not by ghettoizing it in specialist journals, but by bringing together a discipline that took it seriously with one that ought to have done so. The result has been one of the finest venues for truly global philosophy in the Western periodical literature, the only journal that regularly publishes Western and non-Western philosophy and religious studies together without self-consciousness (with an openness also to cognate concerns in Continental, gender and indigenous studies), the only truly cosmopolitan philosophical journal in the English-reading world.

We are all grateful to Charlesworth, his colleagues and his successors for nurturing Sophia in this spirit. The range and quality of the material the journal now publishes is world class and of global scope. We in the editorial collective look forward to a future in which we continue this trajectory, taking the philosophical and religious insights of the world's many intellectual and spiritual traditions seriously and taking the religious and cultural dimensions of Western philosophy seriously in the crosscultural context in which it is prosecuted. We hope that Sophia will continue to encourage those committed to the life of reason and to the enterprise of human betterment to join with their colleagues across disciplinary and cultural divides in the confidence that this spirit of open inquiry and collegiality can only benefit all of us. We thank Max Charlesworth for initiating this venture, and we remain committed to his vision. 